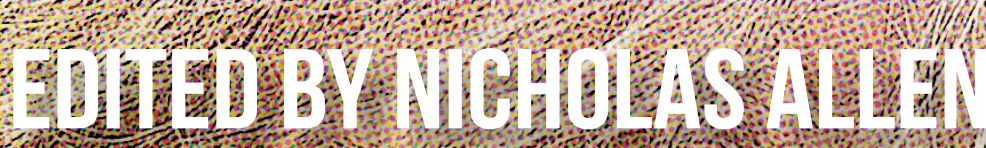

AM OORBART 
BREAKING THE DEADLOCK

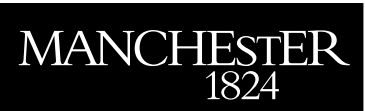

Manchester University Press 
Nicholas Allen and John Bartle - 9781526152374 


\title{
Breaking the deadlock
}

\section{Britain at the polls, 2019}

\author{
Edited by Nicholas Allen \\ and John Bartle
}

Manchester University Press 
While copyright in the volume as a whole is vested in Manchester University Press, copyright in individual chapters belongs to their respective authors, and no chapter may be reproduced wholly or in part without the express permission in writing of both author and publisher.

Published by Manchester University Press

Oxford Road, Manchester M13 9PL

www.manchesteruniversitypress.co.uk

British Library Cataloguing-in-Publication Data

A catalogue record for this book is available from the British Library

ISBN 9781526162786 hardback

ISBN 9781526152367 paperback

First published 2021

The publisher has no responsibility for the persistence or accuracy of URLs for any external or third-party internet websites referred to in this book, and does not guarantee that any content on such websites is, or will remain, accurate or appropriate.

Cover image: Leon Neal/Getty Images

Typeset

by Sunrise Setting Ltd, Brixham 